\title{
Seasonal evolution of water contributions to discharge from a Greenland outlet glacier: insight from a new isotope-mixing model
}

\author{
Maya P. BHATIA, ${ }^{1}$ Sarah B. DAS, ${ }^{2}$ Elizabeth B. KUJAWINSKI, ${ }^{3}$ Paul HENDERSON, ${ }^{3}$ \\ Andrea BURKE, ${ }^{1}$ Matthew A. CHARETTE ${ }^{3}$ \\ ${ }^{1}$ MIT/WHOI Joint Program in Oceanography/Applied Ocean Sciences and Engineering, Department of Geology and \\ Geophysics, Woods Hole Oceanographic Institution, Woods Hole, Massachusetts 02543, USA \\ E-mail: mayab@mit.edu \\ ${ }^{2}$ Department of Geology and Geophysics, Woods Hole Oceanographic Institution, Woods Hole, Massachusetts 02543, USA \\ ${ }^{3}$ Department of Marine Chemistry and Geochemistry, Woods Hole Oceanographic Institution, Woods Hole, \\ Massachusetts 02543, USA
}

\begin{abstract}
The Greenland ice sheet (GrIS) subglacial hydrological system may undergo a seasonal evolution, with significant geophysical and biogeochemical implications. We present results from a new isotope-mixing model to quantify the relative contributions of surface snow, glacial ice and delayed flow to the bulk meltwater discharge from a small $\left(\sim 5 \mathrm{~km}^{2}\right)$ land-terminating GrIS outlet glacier during melt onset (May) and at peak melt (July). We use radioactive $\left({ }^{222} \mathrm{Rn}\right)$ and stable isotopes $\left({ }^{18} \mathrm{O}\right.$, deuterium) to differentiate the water source contributions. Atmospherically derived ${ }^{7} \mathrm{Be}$ further constrains meltwater transit time from the glacier surface to the ice margin. We show that $(1){ }^{222} \mathrm{Rn}$ is a promising tracer for glacial waters stored at the bed and (2) a quantitative chemical mixing model can be constructed by combining ${ }^{222} \mathrm{Rn}$ and the stable water isotopes. Applying this model to the bulk subglacial outflow from our study area, we find a constant delayed-flow (stored) component from melt onset through peak melt. This component is diluted first by snowmelt and then by increasing glacial ice melt as the season progresses. Results from this pilot study are consistent with the hypothesis that subglacial drainage beneath land-terminating sections of the GrIS undergoes a seasonal evolution from a distributed to a channelized system.
\end{abstract}

\section{INTRODUCTION}

The Greenland ice sheet (GrlS) contributes significant quantities of meltwater to the surrounding North Atlantic and Arctic Oceans (Solomon and others, 2007). During the high-melt year of 2007, for example, the GrlS contributed an estimated $523 \mathrm{~km}^{3} \mathrm{a}^{-1}$ surface runoff (Mernild and others, 2009), equivalent to the combined mean annual discharge from the four large North American pan-Arctic rivers, Yukon, Mackenzie, Peel and Beck (Shiklomanov, 2009). Recent evidence that a large fraction of annual surface meltwater likely drains to the bed of the GrIS (McMillan and others, 2007; Das and others, 2008; Krawczynski and others, 2009) suggests that significant portions of the GrIS subglacial hydrological system may undergo a seasonal evolution, akin to those observed beneath alpine glaciers (Shepherd and others, 2009; Bartholomew and others, 2010). This routing suggests there is potential for substantial meltwater interaction with underlying subglacial till and bedrock along seasonally evolving flow paths. Despite recent interest in the GrIS subglacial hydrological system (Box and Ski, 2007; Joughin and others, 2008; Shepherd and others, 2009; Bartholomew and others, 2010; Tsai and Rice, 2010), understanding of the subglacial drainage seasonal evolution remains limited and poorly constrained.

In alpine glacial systems, subglacial flow paths can vary seasonally between two end-member systems: channelized drainage (quick flow) and distributed drainage (delayed flow) (Paterson, 1994). Channelized drainage systems are a series of large tunnels incised into the bedrock, the overlying ice or the till, which facilitate localized and rapid water flow $\left(\sim 1 \mathrm{~m} \mathrm{~s}^{-1}\right)$ to the glacier front. They are prevalent at the peak of the summer melt season (Paterson, 1994; Benn and Evans, 1998) and transport the bulk of surface ice melt that has drained to the bed (Richards and others, 1996; Nienow and others, 1998). In comparison, distributed drainage systems, envisioned as a series of linked cavities, lie along the ice/bed interface, and may include a constant source of water from basal ice melt and groundwater in contact with glacial till (Paterson, 1994). Such systems have characteristically slower water transit times $\left(\sim 0.01 \mathrm{~m} \mathrm{~s}^{-1}\right)$, higher water pressures and are water-full for most of the year (Richards and others, 1996; Benn and Evans, 1998). Additionally, they may transport a significant proportion of early-season snowmelt to the glacier front (Nienow and others, 1998).

The seasonal evolution of subglacial drainage conditions has important geophysical and biogeochemical implications. From a geophysical perspective, the partitioning of meltwater between these two different drainage systems strongly influences basal water pressures and thus sliding velocities (Paterson, 1994). From a biogeochemical perspective, the degree of water/rock contact dictates the chemical enrichment of discharge waters exported to surrounding marine ecosystems, and may fuel subglacial microbial processes (Sharp and others, 1999; Skidmore and others, 2000). Microbial communities could in turn facilitate the release of additional nutrients and metals, amplify chemical weathering reactions and/or utilize previously overridden organic carbon (Tranter and others, 2002; Wadham and others, 2008; Bhatia and others, 2010). Thus, the geochemical cycles of major and minor elements in the coastal waters surrounding the GrIS may be strongly influenced by the temporal dynamics of subglacial discharge (as observed 
in other regions: Raiswell and others, 2006; Hood and Scott, 2008; Hood and others, 2009), and in particular by the release of water that has been stored at the bed.

The development of a chemical mixing model that can successfully differentiate water source contributions and subglacial flow paths will complement existing geophysical and active-tracer methods used to study seasonally evolving subglacial hydrological systems (Nienow and others, 1998; Bartholomew and others, 2010). The interaction of surface meltwater with the glacier bed alters its chemical composition from dilute snow- and ice melt to chemically enriched subglacial discharge waters. Thus, in theory, variations in solute concentrations could be used to infer the evolution of the subglacial drainage network by differentiating water source contributions. This approach is promising because distributed drainage systems produce discharge waters with significantly enriched chemical signatures due to the longer residence time at the bed compared to channelized drainage systems. Initial mixingmodel efforts based the separation of discharge components on bulk properties such as electrical conductivity (EC) (Collins, 1979; Gurnell and Fenn, 1984). However, a model with EC as its defining chemical parameter is poorly constrained because EC is not conservative in glacial systems, and is subject to temporal variations in chemical signature and to post-mixing solute acquisition (Sharp and others, 1995). Consequently, individual dissolved species (e.g. sulfate, chloride) whose provenance is exclusive to specific discharge components have been increasingly used instead of EC (Tranter and Raiswell, 1991; Brown and others, 1994; Tranter and others, 1997; Mitchell and others, 2001). Despite this progress, discharge component separations remain challenging because individual solutes may not retain unique signatures over time and may be involved in subglacial biological reactions across glacial catchments (Sharp and others, 1995; Brown, 2002). Thus, the potential of hydrochemical separation methods in glacier systems has yet to be fully realized (Sharp and others, 1995; Brown, 2002).

Here we introduce a new multi-component isotopemixing model combining the radioactive isotope radon-222 $\left({ }^{222} \mathrm{Rn}\right)$ with the stable water isotopes oxygen-18 $\left({ }^{18} \mathrm{O}\right)$ and deuterium (D) as passive flow tracers. These natural isotopic tracers have unique end-member signatures for different reservoirs ultimately contributing to the total glacial outflow, and are not subject to additional post-mixing enrichment or alteration. We then apply this model to quantify the relative contributions of different water reservoirs to the bulk meltwater discharge at a small landterminating outlet glacier along the western margin of the GrIS in three stages: (1) identified conceptual end-member water reservoirs (surface snow, glacial ice and delayed flow), (2) identified unique passive flow isotopic tracers for each water reservoir $\left(\delta^{18} \mathrm{O}, \mathrm{D}\right.$ and $\left.{ }^{222} \mathrm{Rn}\right)$, and (3) applied end-member mixing analysis to estimate relative contributions of each conceptual water reservoir. We limit our separation to these three conceptual reservoirs because hydrographic separation of all potential drainage components is not possible without additional isotopes or endmember analyses. Finally, we investigate the potential for using beryllium-7 ( $\left.{ }^{7} \mathrm{Be}\right)$, a naturally occurring radioisotope produced in the atmosphere, as a tracer for the transit of snowmelt through the subglacial drainage system. To our knowledge, this is the first time that beryllium has been used in a glacial system as a tracer of hydrological flow.
Through the application of radioisotopes, this pilot study represents a new direction in the use of chemical mixing models to delineate subglacial drainage structure, even though full hydrograph separation of all potential drainage components remains elusive.

\section{MODEL THEORY}

The basic tenets of radon radiochemistry suggest that it has the potential to be an effective tracer of delayed-flow basal waters characteristic of distributed subglacial drainage systems. Radon, an inert noble gas, is a daughter product of radium-226 within the uranium-238 decay series that is naturally present in soil, sediment and rocks. Since the uranium content of solids and the degree of water/rock interaction will determine the amount of radon enrichment in a given water parcel, groundwater will be highly enriched in radon, as should any surface meltwater or basal ice melt that has been stored subglacially. In contrast, surface snowmelt and glacial ice melt that is quickly routed through the subglacial environment has minimal lithogenic sediment contact, and so should be relatively devoid of radon. Radon has been successfully applied as a tracer of submarine groundwater discharge (Cable and others, 1996; Corbett and others, 1997; Burnett and Dulaiova, 2003) but has only recently been applied in a glacial setting (Kies and others, 2010). Moreover, the high uranium content of the Greenland fractured silicate bedrock suggests that waters in contact with the GrlS subglacial environment will be particularly enriched in radon (Kraemer and Genereux, 1998).

Our new model is also based on the hypothesis that the surface snow and glacial ice at a GrlS outlet glacier have unique $\delta^{18} \mathrm{O}$ and $\delta \mathrm{D}$ signatures. Stable water isotopes have been used extensively in glacial settings for a variety of applications from ice-core paleotemperature reconstructions (e.g. Jouzel and others, 1997) to delineation of drainage basins on the GrlS (Reeh and Thomsen, 1993). The GrIS margin, in contrast to alpine catchments (Theakstone, 2003), possesses large isotopic differences between snow and ice components (e.g. Reeh and Thomsen, 1993). This is because seasonal surface snow carries the enriched signature of present-day precipitation at relatively high temperatures and low elevation across the ablation zone, whereas underlying marginal glacial ice will have comparatively more depleted values, reflecting its depositional and flow history from higher elevations and/or colder times (Dansgaard and others, 1971).

\section{FIELD SITE AND SAMPLING OVERVIEW}

Sampling for this study was conducted at two primary field locations along the GrIS southwestern margin. Samples were collected in 2008 in the vicinity of a small $\left(\sim 5 \mathrm{~km}^{2}\right.$; see Section 3.3 for more details) land-terminating outlet glacier $125 \mathrm{~km}$ south of Jakobshavn Isbræ ('N' glacier; $68^{\circ} 02^{\prime} 34^{\prime \prime} \mathrm{N}$, $\left.50^{\circ} 16^{\prime} 08^{\prime \prime} \mathrm{W}\right)$, with a surface elevation range from $\sim 100$ to $\sim 500 \mathrm{~m}$ (Fig. 1a and b). Supraglacial samples were collected from surface snow and a meltwater pond on the surface of ${ }^{N} \mathrm{~N}^{\prime}$ glacier (Fig. 1c), and glacial ice samples at the margin of the glacier; subglacial samples were collected from the outflow stream (Fig. 1d) exiting the base of the glacier at two locations: the mouth where the outflow first emerged, and a downstream site $\sim 0.15 \mathrm{~km}$ from the outflow mouth. 

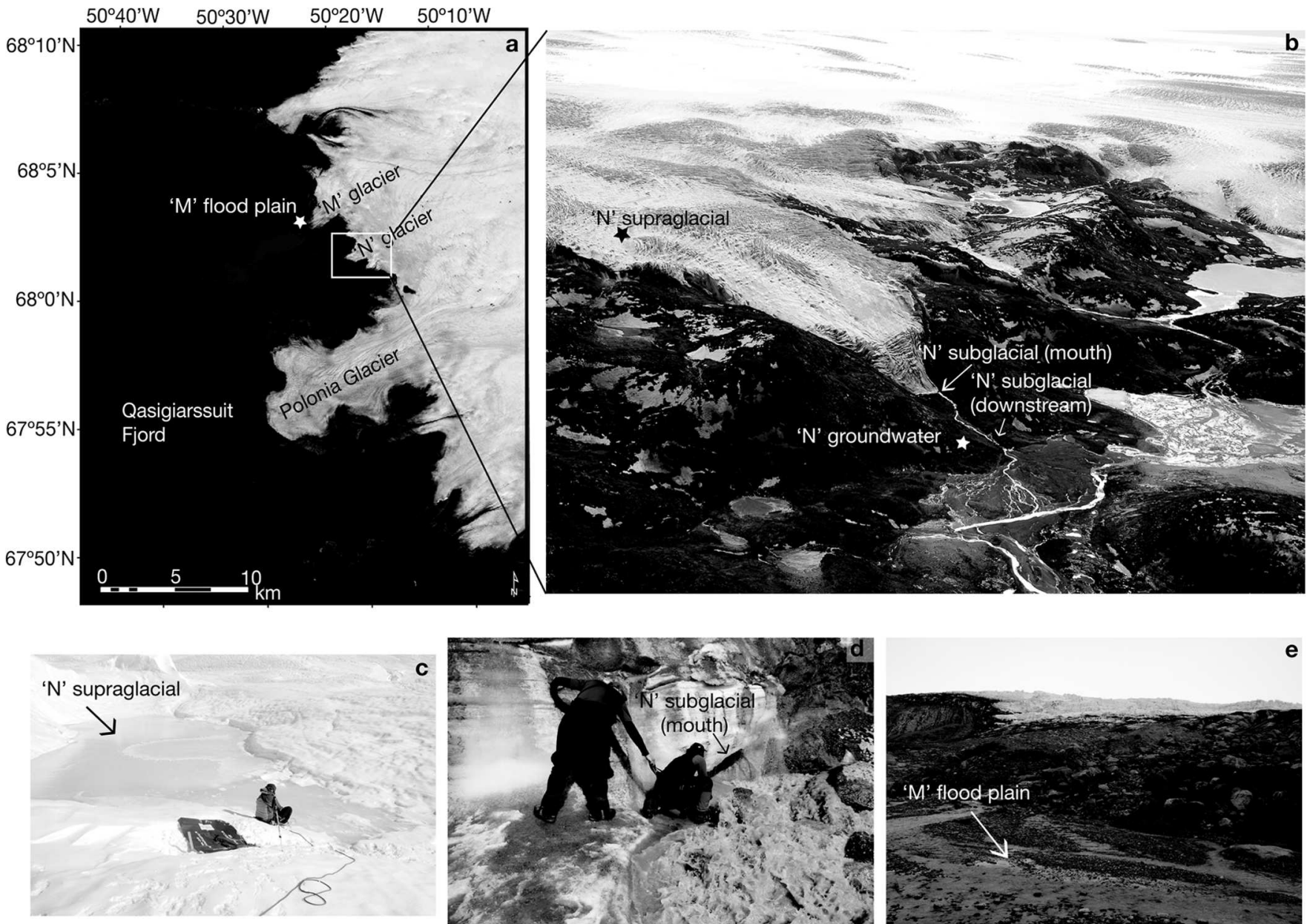

Fig. 1. (a) Landsat image of the 2008 ice-margin field site. Sampling was concentrated at ' $N$ ' glacier and on the ' $M$ ' flood plain. (b) Air photo of the land-terminating outlet glacier (' $\mathrm{N}$ ' glacier) focused upon in this study, with specific sample sites labeled. (c) Photo of the supraglacial pond sampled on the surface of ' $N$ ' glacier. (d) Photo of the mouth of the ' $N$ ' glacier outflow stream. (e) Photo of the ' $M$ ' flood-plain sample site.

Groundwater samples were taken from the bank of the ' $N$ ' glacier proglacial stream and the flood plain of an adjacent larger glacier ('M' glacier) (Fig. 1e). Most samples were acquired while field personnel were on-site in late spring (16 May-1 June) and at the height of the summer melt season (10-17 July); automated instrumentation was used to measure and/or sample selected parameters between 2 June and 15 July. Constraints on end-member values were supplemented with supraglacial snow, ice and meltwater samples collected in July 2007 and 2008 within the ablation zone (980 m elevation) $70 \mathrm{~km}$ north of the primary study site $\left(68^{\circ} 34^{\prime} 16^{\prime \prime} \mathrm{N}, 49^{\circ} 21^{\prime} 29^{\prime \prime} \mathrm{W}\right)$.

\subsection{Meteorological measurements}

Local meteorological conditions were obtained using a HOBO U30-NRC weather station equipped with a tippingbucket rain gauge and data logger installed at $100 \mathrm{~m}$ elevation and $\sim 1.5 \mathrm{~m}$ above the ground in the proglacial area in the vicinity of ' $N$ ' glacier. Shielded air temperatures and precipitation $(0.2 \mathrm{~mm}$ resolution) were recorded every 5 min for the duration of the 2008 field season (16 May17 July) with some gaps (73 min on day 138,7 min on day 146 , and 72.45 hours from day 151 to day 154). Hourly and daily moving averages were calculated for temperature, and daily total values were summed for precipitation. All times are reported in Greenland local time (GMT $-3 \mathrm{~h})$.

\subsection{Discharge measurements}

Stream discharge was measured at the ' $N$ ' glacier outflow stream using the velocity-area method and pressure transducers (HOBO U20 Water Level Logger and InSitu Level TROLL 300 Logger) at a location $\sim 0.15 \mathrm{~km}$ downstream of the glacier mouth. Stream velocities were measured using a manual flowmeter (General Oceanics Mechanical Flow-meter, model 2030R). A horizontal transect was established across the stream, and triplicate velocity measurements were taken at evenly spaced subsections (verticals) along the stream transect. The triplicate measurements were averaged to produce a single velocity at each vertical. Discharges for each stream subsection were calculated as the product of the subsection velocity and area (Dingman, 2002) and summed to obtain a total stream discharge $\left(\mathrm{m}^{3} \mathrm{~s}^{-1}\right)$. Pressure transducers were used to continuously measure stream stage (depth). Water pressure was sensed in 10 min intervals from 31 May (19:00) to 16 July, and was converted to stream stage after correction for atmospheric pressure using a record sensed by an InSitu BaroTROLL Logger. A stage-discharge rating curve $\left(r^{2}=0.76, p<0.01\right)$ was developed using 12 discharge measurements. The rating curve was used to produce a continuous discharge record for the period with continuous stage measurements with point discharges only available from 19 to 27 May. Total meltwater discharge measured 
from ' $N$ ' glacier between 31 May and 16 July is $6.4 \times 10^{6} \mathrm{~m}^{3}$. The error associated with the discharge is estimated to be $\pm 7 \%$ (following Dingman, 2002).

\subsection{Catchment delineation}

Lacking adequately resolved ice thickness and surface and basal topography for this region, we rely on interferometric synthetic aperture radar (InSAR)-derived ice velocity (personal communication from I. Joughin, 2011) to delineate the ' $N$ ' glacier surface area. We defined the catchment area at the downstream end to be bounded by the margins of the outlet glacier at the ice-sheet edge. We delimited the top of the catchment area where the background ice-sheet flow diverged from ' $\mathrm{N}$ ' glacier. We were further limited in this approach by the coarse resolution $(500 \mathrm{~m})$ of the InSAR, so we defined divergence as separation of streamlines by one or more grid spacings. Using this method, we estimate the glacier length to be $5 \mathrm{~km}$ and the surface area to be $5 \mathrm{~km}^{2}$, which we defined as the catchment area for the purposes of evaluating surface meltwater input. To evaluate the reasonableness of this estimate, we calculated the total surface melt over this area required to match the cumulative discharge measured at the front of ' $N$ ' glacier. This calculation yielded a mean melt rate of $\sim 0.03 \mathrm{~m} \mathrm{~d}^{-1}$ (i.e. $1.28 \mathrm{~m} / 46$ days), a value well within the range of summer melt rates previously reported for the western margin of the GrIS (Box and others, 2006), thus providing an independent assessment of our catchment area.

\section{END-MEMBER WATER RESERVOIRS AND ISOTOPE MEASUREMENTS}

Three conceptual end-member water reservoirs contributing to the bulk subglacial discharge from ' $\mathrm{N}$ ' glacier were defined: (1) surface snow, (2) glacier ice and (3) delayed flow, where surface snow and glacier ice represent water sources, and delayed flow is a hydrological flow path. Samples were collected from the bulk discharge as well as each end-member (where possible) across the catchment. Samples were then analyzed for $\delta^{18} \mathrm{O}, \delta \mathrm{D},{ }^{222} \mathrm{Rn}$ and ${ }^{7} \mathrm{Be}$. In this study, delayed flow is operationally defined as water stored at the base on a timescale of days to weeks. These waters could consist of supraglacial waters stored at the base, basal-ice melt and groundwater. The timescale is dictated by the time required for radon $\left(\tau^{1 / 2}=3.8\right.$ days $)$ to approach secular equilibrium activity with its parent radium226. At this activity, the production rate of radon is equal to its decay rate, and the radon content of waters stored at the bed is constant.

\subsection{Stable water isotopes}

Both seasonal-snow and glacial-ice $\delta^{18} \mathrm{O}$ and $\delta \mathrm{D}$ values vary with surface elevation, so samples were collected from this study to constrain these values. Samples include measurements from surface snow ( $300 \mathrm{~m}$ elevation), glacial ice ( $\sim 100, \sim 300$ and $\sim 1000 \mathrm{~m}$ elevation), groundwater ( $\sim 100 \mathrm{~m}$ elevation) and basal ice ( $\sim 100 \mathrm{~m}$ elevation). We then estimated the range of expected $\delta^{18} \mathrm{O}$ values over the ' $\mathrm{N}^{\prime}$ glacier catchment (100-500 m surface elevation). Snow $\delta^{18} \mathrm{O}$ values were estimated using a $0.5 \%$ depletion per $100 \mathrm{~m}$ rise in elevation to account for the effect of altitude on $\delta^{18} \mathrm{O}$ (Clark and Fritz, 1997). Glacial ice $\delta^{18} \mathrm{O}$ values were estimated using an empirical relationship defined by Reeh and Thomsen (1993) at a nearby GrIS location. The average difference $\left(+2.5 \%\right.$ ) between the measured ice $\delta^{18} \mathrm{O}$ at both 100 and $300 \mathrm{~m}$ and that calculated using the relationship defined by Reeh and Thomsen (1993) was used to correct the calculated $\delta^{18} \mathrm{O}$ ice value at $500 \mathrm{~m}$. Bulk discharge samples for $\delta^{18} \mathrm{O}$ and $\delta \mathrm{D}$ measurements from the ' $\mathrm{N}$ ' glacier outflow stream mouth and downstream sites were also collected. The discharge samples were collected at least daily from 18 May to 1 June and 10 to 16 July. Between 2 June and 9 July an ISCO 3700 autosampler (Teledyne Isco Inc.) was used to collect samples in intervals ranging from 1.5 to 4.5 days.

All samples were collected in acid-cleaned and samplerinsed 250 or $1000 \mathrm{~mL}$ polypropylene bottles from which two $10 \mathrm{~mL}$ aliquots were taken for $\delta^{18} \mathrm{O}$ and $\delta \mathrm{D}$ analysis. Samples were frozen upon return to the laboratory until analysis. Thawed water samples were analyzed for $\delta^{18} \mathrm{O}$ and $\delta D$ at the University of California Davis Stable Isotope Facility on a Laser Water Isotope Analyzer V2 (Los Gatos Research, Inc., Mountain View, CA, USA) with precisions of $\leq 0.3 \%$ for $\delta^{18} \mathrm{O}$ and $\leq 0.8 \%$ for $\delta \mathrm{D}$.

\subsection{Radon-222}

Water samples were collected for end-member ${ }^{222} \mathrm{Rn}$ activity from a supraglacial meltwater pond near the edge of ' $N$ ' glacier (22 and 31 May), from groundwater along the stream bank $0.15 \mathrm{~km}$ from the mouth of ' $\mathrm{N}$ ' glacier (25 May) and from groundwater in the flood plain of ' $\mathrm{M}$ ' glacier (28 May). Groundwater samples were taken at $\sim 0.4 \mathrm{~m}$ depth, using a stainless-steel drive point piezometer. Daily ' $N$ ' glacier outflow samples were collected on 18, 21-23, 27 and 29-31 May and 10-16 July from the mouth of ' $N$ ' glacier. Higher-resolution time-series samples (6 hour intervals) were taken on 31 May and 12 July. EC was also measured on-site using a Russell RF060C meter (Thermo Electron). Radon-222 samples were collected without headspace in glass $250 \mathrm{~mL}$ bottles, and were quantified using a RAD-7 continuous radon monitor (Durridge Inc.) (Burnett and Dulaiova, 2003). Typical RAD-7 uncertainties were $14 \%$, with a range of $8-37 \%$ for the lowest measured ${ }^{222} \mathrm{Rn}$ activities in this study. All samples were analyzed within 24 hours of collection. Results were corrected for radioactive decay between the time of collection and analysis and reported as an activity in disintegrations per minute per liter $\left(\mathrm{dpm} \mathrm{L} \mathrm{L}^{-1}\right)$. A model II (geometric mean) regression was used to compare the radon and EC data since both are measured (dependent) parameters with different units (Ricker, 1973; Sofal and Rohlf, 1995).

In order to determine the maximum potential radon activities in saturated subglacial sediments, laboratory equilibration experiments were conducted using sediment collected from the proglacial area at the mouth of the ' $N$ ' glacier outflow $(n=1)$ and downstream $(n=2)$. Approximately $100 \mathrm{~g}$ of wet sediment were incubated with $\sim 0.5 \mathrm{~L}$ radium-free water in sealed $1 \mathrm{~L}$ high-density polyethelyene bottles, following methods described by Dulaiova and others (2008). The sediment was incubated for at least 3 weeks and the radon was subsequently quantified via an alpha scintillation technique. Each sediment equilibration sample was analyzed twice. The measured radon activities $\left(\mathrm{dpm} \mathrm{g}^{-1}\right)$ in the wet sediment were converted to pore-water radon activities $\left(\mathrm{dpm} \mathrm{L}^{-1}\right)$ using a wet bulk density of $2.3 \mathrm{~g} \mathrm{~cm}^{-3}$ and a porosity of 0.2 (Dulaiova and others, 2008). 
Table 1. Isotope tracer values used to initially solve the endmember mixing model equations (Equations (1-4)). For the delayedflow waters a basal ice sample collected at $100 \mathrm{~m}$ elevation was used for the $\delta^{18} \mathrm{O}$ and $\delta \mathrm{D}$ ratios, while the maximum ' $\mathrm{N}$ ' glacier outflow radon activity was used as the ${ }^{222} \mathrm{Rn}$ end-member. The radon activity of the surface snow and glacial ice reservoirs was set to zero

\begin{tabular}{lcccc}
\hline Water source & $\begin{array}{c}\text { Elevation } \\
\mathrm{m}\end{array}$ & $\begin{array}{c}\delta^{18} \mathrm{O} \\
\% 0\end{array}$ & $\begin{array}{c}\delta \mathrm{D} \\
\% 0\end{array}$ & $\begin{array}{c}{ }^{222} \mathrm{Rn} \\
\mathrm{dpm} \mathrm{L} \mathrm{L}^{-1}\end{array}$ \\
\hline Surface snow & 300 & -12.3 & -89.9 & 0 \\
Glacial ice & 300 & -28.2 & -216.1 & 0 \\
Delayed-flow waters & 100 & -29.6 & -227.2 & 209.5 \\
\hline
\end{tabular}

\subsection{Beryllium-7}

Water samples $(\sim 190 \mathrm{~L})$ for measuring ${ }^{7} \mathrm{Be}$ activity were collected from a supraglacial meltwater pond near the edge of ' $\mathrm{N}$ ' glacier (22 May) and from a supraglacial meltwater stream at the inland ice-sheet site (20 July). Two ' $\mathrm{N}$ ' glacier discharge samples were collected for ${ }^{7} \mathrm{Be}$ (21 May and 11 July). Water was collected in a large plastic container and processed on-site. The supraglacial samples were not filtered prior to collection due to the lack of particles in these waters; however, the ' $\mathrm{N}$ ' glacier outflow stream sample was filtered through a $10 \mu \mathrm{m}$ Hytrex II cartridge prior to collection. A $1 \mathrm{~mL}$ aliquot of stable ${ }^{9} \mathrm{Be}(10000 \mathrm{ppm})$ was added as a yield monitor, and iron oxide $\left(\mathrm{Fe}(\mathrm{OH})_{3}\right)$ fibers were used to pre-concentrate both the ${ }^{7} \mathrm{Be}$ and ${ }^{9} \mathrm{Be}$ from the water sample (Andrews and others, 2008). Periodic aliquots $(20 \mathrm{~mL})$ of the fiber column filtrate were taken and subsequently analyzed on an inductively coupled plasma mass spectrometer (ICP-MS) at the Woods Hole Oceanographic Institution (WHOI) to determine the collection efficiencies for ${ }^{7} \mathrm{Be}$ (Andrews and others, 2008). The fibers were combusted at $820^{\circ} \mathrm{C}$ for 16 hours and the ash was analyzed for ${ }^{7} \mathrm{Be}$ via gamma spectroscopy (Andrews and others, 2008). Samples were counted for 2 days, and corrected for decay since the time of collection. Beryllium recovery on the fibers averaged $75 \%$. Results are presented as activities in units of $d p m \mathrm{~L}^{-1}$.

\section{MODEL DESCRIPTIONS}

\subsection{Isotope-mixing model}

A multi-component isotope-mixing model using the stable water isotope values and radon measurements described above was constructed to quantify the relative fraction of flow contributed by each end-member water source to the total discharge exiting ' $N$ ' glacier using

$$
\begin{gathered}
\text { Mass conservation: } f_{1}+f_{2}+f_{3}+f_{4}=1 \\
\delta^{18} \mathrm{O}: f_{1} \delta^{18} \mathrm{O}_{1}+f_{2} \delta^{18} \mathrm{O}_{2}+f_{3} \delta^{18} \mathrm{O}_{3}=\delta^{18} \mathrm{O}_{4} \\
\delta \mathrm{D}: f_{1} \delta \mathrm{D}_{1}+f_{2} \delta \mathrm{D}_{2}+f_{3} \delta \mathrm{D}_{3}=\delta \mathrm{D}_{4} \\
{ }^{222} \mathrm{Rn}: f_{1}{ }^{222} \mathrm{Rn}_{1}+f_{2}{ }^{222} \mathrm{Rn}_{2}+f_{3}{ }^{222} \mathrm{Rn}_{3}={ }^{222} \mathrm{Rn}_{4},
\end{gathered}
$$

where $f$ is the fraction of flow and subscripts indicate the following: 1 is the snow end-member, 2 is the glacial ice end-member, 3 is the delayed-flow end-member and 4 is the ' $N$ ' glacier outflow. The end-member water source and ' $N$ '
Table 2. Range of isotope tracer values used in end-member mixing model sensitivity analysis

\begin{tabular}{lccc}
\hline Water source & $\begin{array}{c}{ }^{18} \mathrm{O} \\
\% 0\end{array}$ & $\begin{array}{c}\delta \mathrm{D} \\
\% 0\end{array}$ & $\begin{array}{c}{ }^{222} \mathrm{Rn} \\
\text { dpm L }\end{array}$ \\
\hline Surface snow & -11 to -16 & -78 to -118 & 0 \\
Glacial ice & -25 to -30 & -190 to -230 & 0 \\
Delayed-flow waters & -27 to -30 & -206 to -230 & $200-1600$ \\
\hline
\end{tabular}

glacier outflow stream isotope values (Table 1) were used to solve the system of equations using singular value decomposition. The radon content in the snow and glacial ice endmembers $\left({ }^{222} \mathrm{Rn}_{1}\right.$ and ${ }^{222} \mathrm{Rn}_{2}$ ) was set to zero (negligible in situ source of ${ }^{222} \mathrm{Rn}$ ). To initially solve the model, the highest radon activity measured in the ' $\mathrm{N}$ ' outflow stream $(210 \mathrm{dpm}$ $\mathrm{L}^{-1}$ ) was operationally defined as ${ }^{222} \mathrm{Rn}_{3}$, effectively normalizing the entire dataset to this maximum concentration. In this study the sediment radon flux to the delayed-flow reservoir is assumed to be a continuous, steady-state process, so a loss term due to radioactive decay is not included in the radon end-member mixing equation.

\subsection{Mixing-model sensitivity analysis}

A sensitivity analysis employing a range of end-member values (Table 2) was conducted to put envelopes of uncertainty on the model fraction results $\left(f_{1}, f_{2}, f_{3}\right)$ by simultaneously varying each of the end-member water reservoir values across a range of reasonably determined limits. The range of surface snow $\delta^{18} \mathrm{O}$ values utilized was chosen to incorporate a maximum isotopic depletion from the original snow during metamorphism and melting (Taylor and others, 2001). Though the mean snowmelt will become progressively enriched throughout the summer melt season due to the early removal of isotopically light water (Cooper, 1998; Taylor and others, 2001), this isotopic enrichment is difficult to predict without additional samples of the total snowpack oxygen isotope signature. However, the model results will be most affected by the potential for depleted snow end-member values, which encroach on the glacial ice $\delta^{18} \mathrm{O}$ values. The glacial ice $\delta^{18} \mathrm{O}$ values were chosen to reflect the range of ice isotopic values across the elevation range of the ' $\mathrm{N}$ ' glacier catchment that could potentially contribute to the outflow waters. The range of delayed-flow $\delta^{18} \mathrm{O}$ values employed in the sensitivity analysis encapsulated the $\delta^{18} \mathrm{O}$ content of the groundwater and basal ice at ' $\mathrm{N}$ ' glacier. Corresponding $\delta \mathrm{D}$ ranges for each end-member water source were calculated directly from these $\delta^{18} \mathrm{O}$ values using the global meteoric waterline $\left(\delta \mathrm{D}=8 \delta^{18} \mathrm{O}+10\right)$. The range of potential ${ }^{222} \mathrm{Rn}$ activities in the delayed-flow end-member was defined using the maximum activity measured in the ' $\mathrm{N}$ ' outflow stream as the lower bound and the lowest groundwater radon activity measured in this study as an upper bound. A better estimate of the ${ }^{222} \mathrm{Rn}$ activity in the delayed-flow waters could be attained by sampling outflow waters during the early season before they are diluted by any surface input. This could be achieved with standard automated continuous radon monitors that measure the ${ }^{222} \mathrm{Rn}$ activity of the outflow stream (e.g. Dulaiova and others, 2005; Schmidt and others, 2008). 


\subsection{Transit time model}

The surface snow and glacial ice fraction results $\left(f_{1}\right.$ and $\left.f_{2}\right)$ from the isotope model were used to estimate a transit time for snowmelt from the surface to its exit at the glacier front using ${ }^{7} \mathrm{Be} .{ }^{7} \mathrm{Be}$ is continuously produced in the atmosphere and is deposited to the surface environment (e.g. the icesheet surface) via wet (precipitation events) and dry (aerosol) deposition (Nimz, 1998). Its unique atmospheric source in combination with its short half-life $\left(\tau_{1 / 2}=53.3\right.$ days) suggests that ${ }^{7} \mathrm{Be}$ should be present in the surface snow end-member, while occurring below detection levels in glacial ice and delayed-flow waters that are older than $\sim 300$ days. Thus, assuming constant production on the surface and no ${ }^{7} \mathrm{Be}$ in the delayed-flow reservoir $\left(f_{3}\right)$, the ${ }^{7}$ Be activity in the outflow stream can be described using a steady-state model:

$$
{ }^{7} \mathrm{Be}:\left(f_{1}{ }^{7} \mathrm{Be}_{1, t 0}+f_{2}{ }^{7} \mathrm{Be}_{2}\right)_{t 0} \mathrm{e}^{-\lambda t}={ }^{7} \mathrm{Be}_{4 \text { eff }, t}
$$

where $t$ is time (days), $\lambda$ is the decay constant for ${ }^{7} \mathrm{Be}$ $\left(0.013 \mathrm{~d}^{-1}\right),{ }^{7} \mathrm{Be}_{1, t 0}$ is the ${ }^{7} \mathrm{Be}$ activity of the surface snow end-member water source, ${ }^{7} \mathrm{Be}_{2}$ is the ${ }^{7} \mathrm{Be}$ activity of the glacial ice, and ${ }^{7} \mathrm{Be}_{4 \text { eff, } t}$ is the effective ${ }^{7} \mathrm{Be}$ activity in the ${ }^{\mathrm{N}} \mathrm{N}$ glacier outflow stream. ${ }^{7} \mathrm{Be}_{4 \mathrm{eff}, t}$ accounts for any scavenging of ${ }^{7} \mathrm{Be}$ onto subglacial particles and is calculated as the sum of the ${ }^{7} \mathrm{Be}$ in the ${ }^{\prime} \mathrm{N}^{\prime}$ glacier outflow stream $\left({ }^{7} \mathrm{Be}_{\text {dissolved }}\right)$ and the ${ }^{7} \mathrm{Be}$ scavenged by particles in the subglacial environment $\left({ }^{7} \mathrm{Be}_{\text {particulate }}\right)$. The former was measured in the ' $\mathrm{N}$ ' outflow stream on 21 May, and the latter was estimated using

$$
{ }^{7} \mathrm{Be}_{\text {particulate }}=K_{\mathrm{d}} C_{\mathrm{p}} \cdot{ }^{7} \mathrm{Be}_{\text {dissolved }}
$$

where $K_{d}$ is particle-water coefficient $\left(\left(^{7} \mathrm{Be} / \mathrm{mass}\right.\right.$ of particles $) /\left({ }^{7} \mathrm{Be} / \mathrm{mass}\right.$ of water) $)$ and $C_{\mathrm{p}}$ is suspended sediment concentration $\left(\mathrm{mg} \mathrm{mL}^{-1}\right)$ measured in May. A $K_{\mathrm{d}}$ value of 5000 was assumed, which is within the range of previously published ${ }^{7}$ Be $K_{d}$ values $\left(10^{3}-10^{4}\right)$ (Olsen and others, 1986). Rearranging Equation (5) to solve for time yields

$$
t=-1 / \lambda \ln \left(\frac{{ }^{7} \mathrm{Be}_{4 \mathrm{eff}, t}}{f_{1} \cdot{ }^{7} \mathrm{Be}_{1, t 0}+f_{2} \cdot{ }^{7} \mathrm{Be}_{2, t 0}}\right) .
$$

Here time is defined as the transit time from the glacier surface to the front since ${ }^{7} \mathrm{Be}$ is only produced on the surface, and we have accounted for any sinks (scavenging) in the subglacial environment.

\section{RESULTS AND DISCUSSION}

\subsection{Climatology and discharge}

' $N$ ' glacier discharge was highly sensitive to air-temperature fluctuations, with the two clearly co-varying throughout the melt season (Fig. 2a and b). We did not capture the melt onset, as there was already meltwater discharge on our arrival at the field site on 19 May. Nonetheless, a cold period towards the beginning of our record (days 142-144), characterized by subfreezing air temperatures, reduced discharge almost to zero. Following this cold period, air temperature and discharge increased from mid-May to early June as the melt season progressed. Daily-average temperatures at the ice edge then generally remained above $6^{\circ} \mathrm{C}$ for the remainder of the study period. Daily-average discharge also stabilized around $1.6-1.8 \mathrm{~m}^{3} \mathrm{~s}^{-1}$ until late July, when a cold period precipitated a drop in discharge back towards early-season values. We also observed a strong diurnal cycle in subglacial stream discharge that was highly responsive to, although offset from, the insolation-driven diurnal temperature cycle. Peak discharge lagged peak air temperature by an average of 2.4 hours (range $1-5.6$ hours), while the average lag in minimum discharge was 2.7 hours (range 0.354.7 hours) from the minimum temperature. The mean diurnal amplitude in the temperature and discharge records was $7.3^{\circ} \mathrm{C}$ and $0.39 \mathrm{~m}^{3} \mathrm{~s}^{-1}$, with maximum and minimum daily discharges occurring between 15:00 and 21:00 and 4:00 and 8:00, respectively.

\subsection{Radon as a tracer for delayed-flow waters}

We did not detect any radon in a sample from a supraglacial meltwater pond on the surface of ' $\mathrm{N}$ ' glacier, thus confirming our assumption that surface snow and glacial ice would be devoid of radon due to negligible sediment inventories on the ice-sheet surface. Conversely, as expected, radon activities in the groundwater samples were very high $\left(1626 \pm 48.8\right.$ and $\left.2750 \pm 63.3 \mathrm{dpm} \mathrm{L}^{-1}\right)$. These activities were consistent with the laboratory-derived pore-water radon activities (range $1285 \pm 43.3$ to $3045 \pm 132 \mathrm{dpm} \mathrm{L}^{-1}$ ), thus indicating that the groundwater samples collected in this study represent saturated flow. We observed seasonal differences in the amount of radon detected in the ' $\mathrm{N}$ ' glacier outflow stream waters. The mean activity of the May samples was much higher $\left(75.6 \mathrm{dpm} \mathrm{L}^{-1}\right)$ than that of the July samples $\left(25.4 \mathrm{dpm} \mathrm{L}^{-1}\right)$. Furthermore, we observed a greater range in the radon activities of the outflow stream in May (16.9-210 dpm L ${ }^{-1}$ ) compared to July (10.4-35.7 dpm L $\mathrm{L}^{-1}$ ) (Fig. 2c). Thus, during at least some periods in the late spring, the ' $\mathrm{N}$ ' stream outflow waters had high radon activities, whereas at the height of the summer melt season the outflow waters had universally low radon activities. For comparison, the open ocean has an average radon activity of $\sim 0.01 \mathrm{dpm} \mathrm{L} \mathrm{L}^{-1}$ (Broecker and Peng, 1982). In groundwater, radon activities can vary greatly, but, in general, activities range from hundreds to thousands of

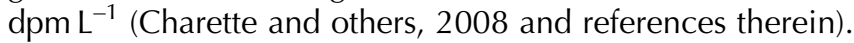
We were not able to resolve a diurnal cycle in the ' $N$ ' outflow radon activity during the 12 July high-resolution time series due to the low activities measured throughout this day (27.3-31.8 dpm $\left.\mathrm{L}^{-1}\right)$. Earlier in the season, however, we found that the maximum daily radon activity on 31 May (75.5 dpm L $\mathrm{L}^{-1}$ at 06:45) occurs within the period when daily discharge was at a minimum (although we lack continuous discharge measurements during that time). Moreover, we observed the lowest radon activity $\left(47.5 \mathrm{dpm} \mathrm{L}^{-1}\right)$ at 18:25, when daily discharge was at a maximum. These preliminary data indicate that radon may be useful in resolving the diurnal contribution of delayed-flow waters to total outflow in the early season, but this application requires more frequent sampling. Thus, we limit further discussion of radon to seasonal trends.

Radon in water that is physically decoupled from its sediment or rock source is subject to decay on a timescale determined by its half-life (Kraemer and Genereux, 1998). Thus, subglacial outflow radon activities in line with published groundwater values require substantial steadystate sediment-water interaction. To quantify the potential for suspended sediment to explain the observed radon values, we collected replicate unfiltered samples from the mouth of the ' $\mathrm{N}$ ' outflow; one sample was analyzed immediately, while the other was measured after one radon half-life. The decay-corrected activities of the samples were 

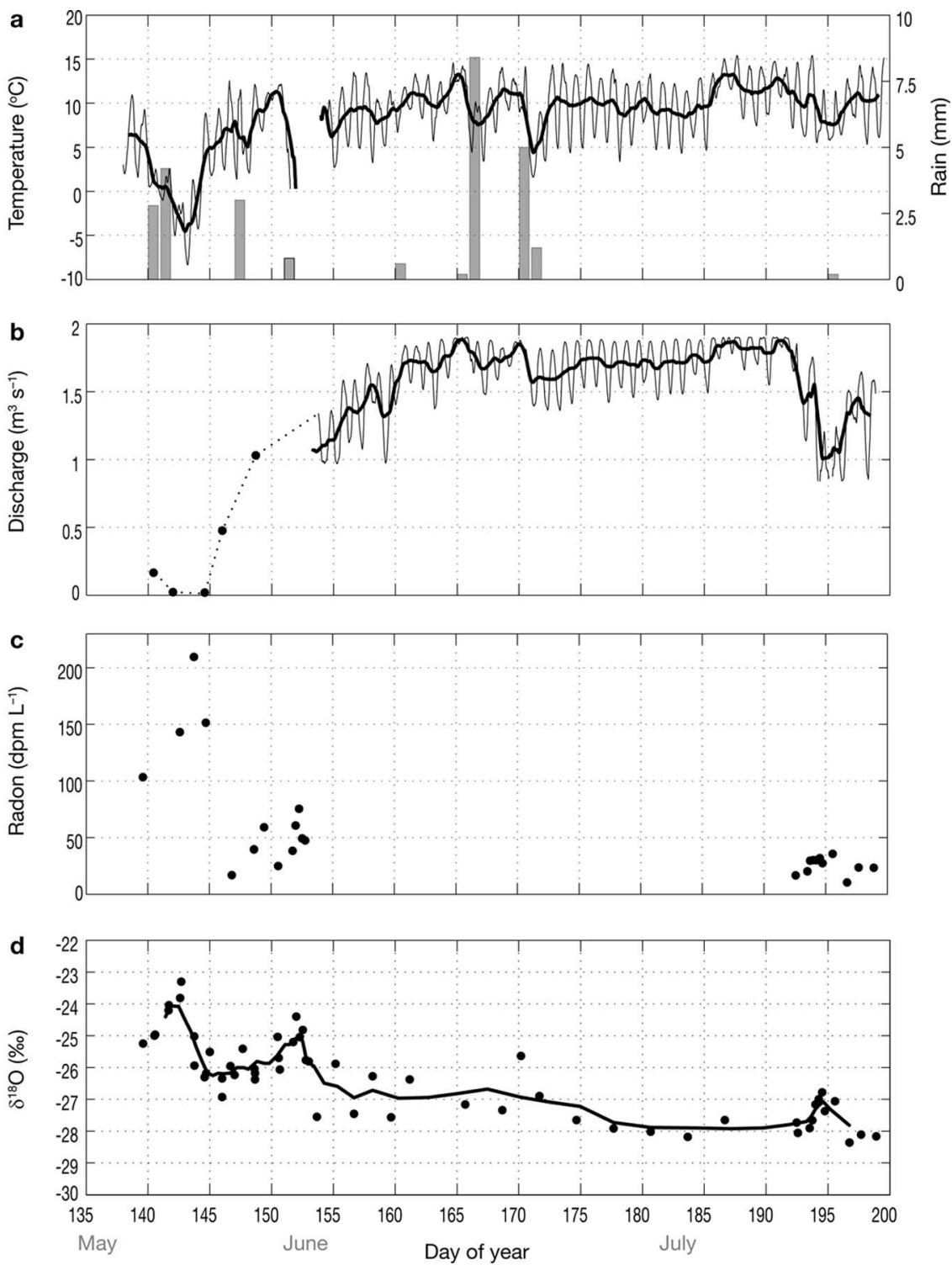

Fig. 2. (a) Plot of 3 hour (thin black line) and daily (thick black line) average air temperatures, with total daily rainfall in the gray bars. (b) Three-hour (thin black line) and daily (thick black line) average discharge at ' $N$ ' glacier. (c) Radon activities. (d) $\delta^{18} \mathrm{O}$ content (black dots) and five-point moving average (black line) in the ${ }^{N} \mathrm{~N}^{\prime}$ glacier outflow stream. The discharge record is confined to point measurements from 19 to 31 May. Discontinuous lines in the temperature and discharge records reflect gaps in the data.

the same, indicating that ${ }^{226} \mathrm{Ra}$ in the stored sample sediment was not a significant source of radon. We therefore conclude that the presence of radon in bulk outflow waters necessitates some delayed-flow component that has had substantial interaction with the bed. As further evidence of this idea, the regression (model II, geometric mean) of radon and EC was significant $\left(r^{2}=0.87\right.$, $p<0.01$ ) (Fig. 3). However, unlike EC, radon is not subject to the dissolution chemistries of a wide range of solutes and thus can potentially be utilized for quantitative hydrograph separation.

\subsection{Radon evasion in subglacial channels}

Although radon is water-soluble, the radon will partition into the air phase in an air-water system (Kraemer and Genereux, 1998). Loss due to evasion is a function of temperature and the amount of radon present in the air, so evasion could be problematic late in the melt season when subglacial channels may not be entirely water-full. Moreover, water flow in the subglacial channels is often faster

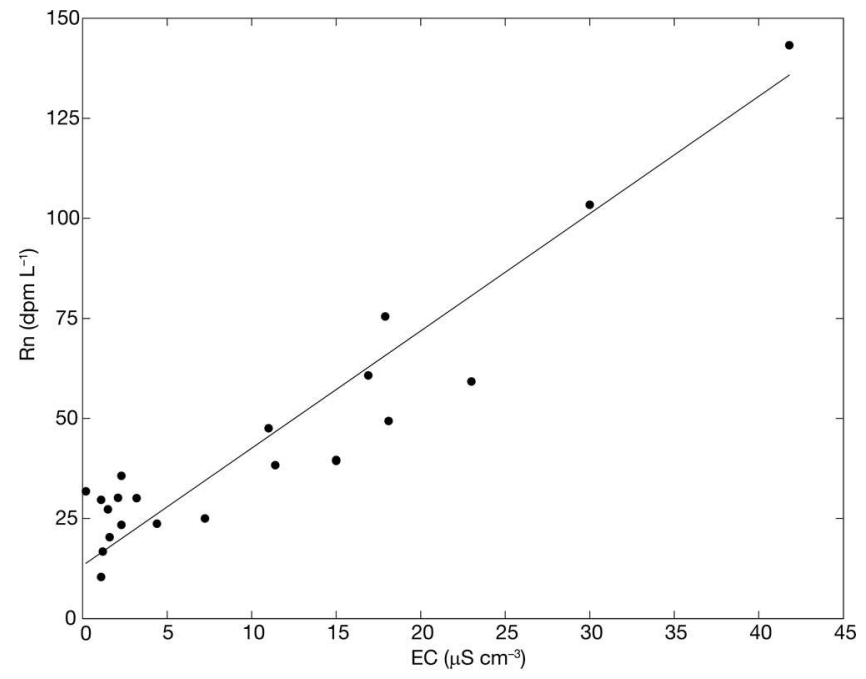

Fig. 3. Model II regression (geometric mean) of EC and radon activity in the ' $\mathrm{N}$ ' glacier outflow stream waters. 
Table 3. ${ }^{222} \mathrm{Rn}$ activities in the ' $\mathrm{N}$ ' glacier outflow stream on falling and rising discharge limbs from 10 to 16 July 2008

\begin{tabular}{lccc}
\hline Julian day & Discharge observations & $\begin{array}{c}\text { Mean daily discharge } \\
\mathrm{m}^{3} \mathrm{~s}^{-1}\end{array}$ & $\begin{array}{c}{ }^{222} \mathrm{Rn} \\
\mathrm{dpm} \mathrm{L}^{-1}\end{array}$ \\
\hline 192 & Start of falling limb & 1.7 & 16.7 \\
193 & Falling limb & 1.5 & 20.3 \\
194 & Falling limb & 1.2 & 31.8 \\
195 & Bottom of falling limb & 1.0 & 35.7 \\
196 & Rising limb & 1.2 & 10.4 \\
197 & Top of rising limb & 1.4 & 23.7 \\
198 & Falling limb & 1.3 & 23.4 \\
& & & \\
\hline
\end{tabular}

and more turbulent at the peak of the summer melt season, which may enhance gas exchange loss (Kraemer and Genereux, 1998). Thus, if evasion were the dominant process influencing radon in the ' $N$ ' glacier outflow stream we would expect to find lower radon activities toward the end of a falling discharge limb. Instead we observed increases in radon during times when discharge was decreasing and subglacial channels were less full (e.g. days 192-195), and the largest radon activities occurred at the discharge minimum (Table 3). Thus, dilution of the delayed-flow waters with radon-free surface input appears to have had the greatest effect on radon values in the ' $N$ ' outflow stream.

\subsection{Water isotopes as a tracer in a GrIS outlet glacier}

We found distinct $\delta^{18} \mathrm{O}$ values for the surface-snow (-11 to $-13 \%$ ) and glacial-ice ( -26 to $-30 \%$ ) end-members measured across our study region (Table 4 ). This difference means that the snow and glacial ice reservoir $\delta^{18} \mathrm{O}$ values do not overlap and thus are useful as passive flow tracers. Conversely, our 'basal-ice' (ice collected at $100 \mathrm{~m}$ elevation at the glacier margin) sample values (-29.6\%) were not sufficiently isotopically distinct from glacial ice values estimated across the surface of the catchment $(-25.5$ to $-28.2 \%$ ) to separate the delayed-flow water source from the glacier ice reservoir. Thus it was necessary to delineate these reservoirs from each other with the radon end-member mixing equation. An additional groundwater sample near the front of ' $\mathrm{N}$ ' glacier also possessed a depleted $\delta^{18} \mathrm{O}$ signature $(-27.8 \%$ ), suggesting that groundwater in this region is derived primarily from glacial ice melt. Although we limit our discussion to the $\delta^{18} \mathrm{O}$ values, the trends observed in the oxygen isotope values are also applicable to the deuterium data, since $\delta^{18} \mathrm{O}$ and $\delta \mathrm{D}$ covary on a global scale (Craig, 1961).

\subsection{Isotope-mixing model}

The end-member mixing equations used in this study assume a simplified drainage system limited to three conceptual end-member water sources: (1) surface snow, (2) glacial ice and (3) delayed-flow waters. This was necessary to determine the applicability of radon as a hydrological tracer in a glacial setting, and to produce an initial chemical mixing model, although we recognize that we have oversimplified the subglacial drainage system by categorizing glacial flow components into three broad water source reservoirs (Sharp and others, 1995).

Model results showed that the snowmelt and delayedflow waters comprised a greater fraction of the total outflow
Table 4. Measured and estimated $(*) \delta^{18} \mathrm{O}$ ratios of surface-snow, glacial-ice and groundwater samples

Water source $\quad \delta^{18} \mathrm{O}$

$100 \mathrm{~m}$ elev. $300 \mathrm{~m}$ elev. $500 \mathrm{~m}$ elev. $1000 \mathrm{~m}$ elev.

\begin{tabular}{lcccc}
\hline Surface snow & $-11 \% *$ & $\begin{array}{c}-12.3 \% \\
(n=1)\end{array}$ & $-13 \% *$ & \\
Glacial ice & $-29.6 \%$ & $-28.2 \% 0$ & $-25.5 \% *$ & $-23.9 \%$ \\
& $(n=2)$ & $(n=3)$ & & $(n=9)$ \\
Groundwater & $-27.8 \%$ & & \\
& $(n=1)$ & & & \\
& & & &
\end{tabular}

in May (Fig. 4a) than in July (Fig. 4b). In May, delayed flow dominated the discharge (mean 41\%), followed by nearly equal contributions from surface snowmelt (mean 23\%) and glacial ice melt (mean 26\%). In July, however, the mean fractional contributions from the surface snowmelt and delayed-flow reservoirs decreased to $6 \%$ and $12 \%$, respectively, while the mean glacial ice contribution rose to $82 \%$. This finding was likely due to the removal of seasonal snow from the glacier surface by this time, and dilution of delayed-flow reservoirs with increased glacial ice melt. Scaling the model results with the measured discharge allowed us to compare the discharge contribution of surface snow, glacial ice and delayed flow to the total ' $N$ ' stream discharge from 18 May to 1 June (Fig. 4c) and 11 to 17 July (Fig. $4 d$ ). The average snow component $(n=11)$ of total discharge decreased by more than half from May (mean $0.17 \pm 0.04 \mathrm{~m}^{3} \mathrm{~s}^{-1}$; 1 standard error) to July (mean $0.07 \pm 0.01 \mathrm{~m}^{3} \mathrm{~s}^{-1}$ ), whereas the average glacial ice component $(n=11)$ more than doubled from May (mean $0.43 \pm 0.10 \mathrm{~m}^{3} \mathrm{~s}^{-1}$ ) to July (mean $1.1 \pm 0.09 \mathrm{~m}^{3} \mathrm{~s}^{-1}$ ). By comparison, the average delayed-flow component $(n=11)$ remained a relatively constant contribution between May $\left(0.19 \pm 0.05 \mathrm{~m}^{3} \mathrm{~s}^{-1}\right)$ and July $\left(0.16 \pm 0.01 \mathrm{~m}^{3} \mathrm{~s}^{-1}\right)$.

The results of our isotope-mixing model were a direct consequence of the shifts we observed in the ${ }^{222} \mathrm{Rn}$ activities and $\delta{ }^{18} \mathrm{O}$ and $\delta \mathrm{D}$ ratios of the ${ }^{\prime} \mathrm{N}$ ' outflow stream composition from May to July. The highest radon activities were found during times of lowest discharge (Fig. 5a). During the 3 day subfreezing period in May when discharge dropped to near zero, radon activities in the ' $\mathrm{N}$ ' outflow stream peaked at $>100 \mathrm{dpm} \mathrm{L}^{-1}$ (Fig. 5a). In July, even though the radon activities were overall much lower than in May, elevated radon $\left(35.7 \mathrm{dpm} \mathrm{\textrm {L } ^ { - 1 }}\right.$ ) coincides with a prominent drop in discharge on day 195 (Fig. 5b). This behavior can best be explained by varying levels of dilution of the delayed-flow waters with a supraglacial water source devoid of radon. This reasoning is consistent with a seasonal evolution of the subglacial drainage structure from a distributed system characterized by chemically enriched outflow waters to a channelized system that facilitates rapid transit of dilute glacial ice melt.

The difference between the stable-isotope signatures of the snow and ice reservoirs at ' $\mathrm{N}$ ' glacier is sufficiently large that a change in $\delta^{18} \mathrm{O}$ runoff composition can likely be attributed to a water source change. In late spring when dischargeis low, and snowmelt feeds a predominantly distributed subglacial drainage system, we measured enriched $\delta^{18} \mathrm{O}$ values in the ' $\mathrm{N}$ ' outflow stream, compared to 

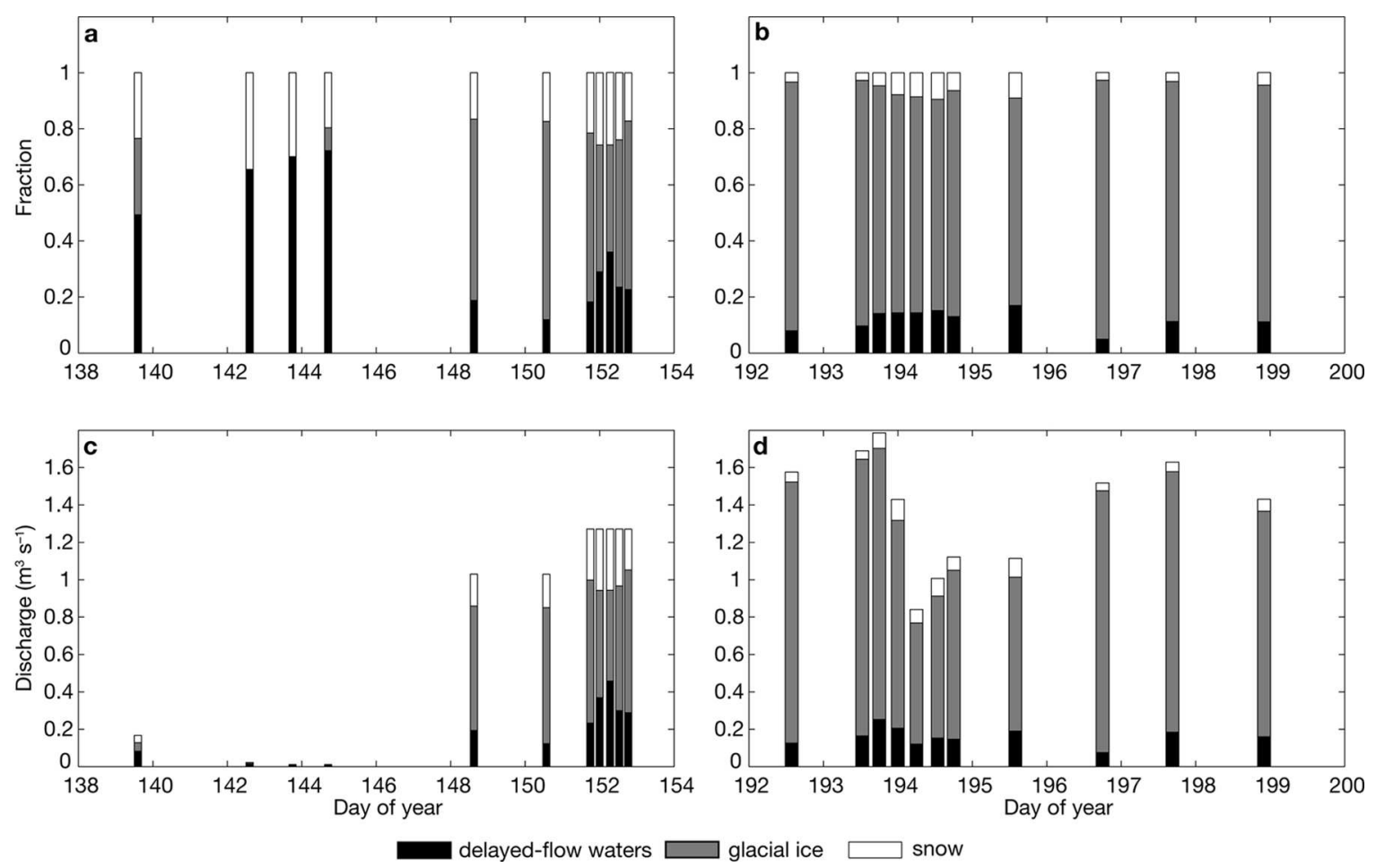

Fig. 4. Stacked bar plots of isotope-mixing model solutions for the fractions of surface snow, glacial ice and delayed-flow waters comprising the ' $\mathrm{N}$ ' glacier outflow stream waters from (a) 18 May to 1 June and (b) 11 to 17 July, and scaled contributions from each reservoir in (c) May and (d) July.

later in the season (Fig. 2d). Indeed, the most enriched values occurred over the 3 day span that discharge dropped to near zero. Subsequently there is a decrease in the stableisotope signature of the ' $N$ ' glacier discharge as the melt season progresses from late spring to the summer. This trend is consistent with a seasonal shift in water source reservoirs from a snow and ice contribution in late spring to a purely glacial ice contribution at the height of the summer melt season.

In addition to the overall seasonal decline, our $\delta^{18} \mathrm{O}$ record exhibited higher-frequency variability, suggesting that changes in meltwater source contributions and/or drainage system evolution may also have occurred during synoptic-scale events. Although we lacked the temporal resolution required to explore this variability in full, one such event late in the melt season is reasonably well resolved. On day 195 there was a notable spike in the ' $N$ ' glacier subglacial stream $\delta^{18} \mathrm{O}$ values above the late-season mean coincident with a prominent drop in air temperature and discharge, and an increase in radon activity (Fig. 2). One possible explanation for this event is cooling air temperatures across the glacier surface leading to a decrease in $\delta^{18} \mathrm{O}$-depleted glacier ice melt. This decrease in total surface meltwater input to the subglacial resulted in a relatively higher base flow contribution (characterized by residual stored $\delta^{18} \mathrm{O}$-enriched snowmelt) to the bulk runoff during this event. Another possible explanation for this isotopic excursion is a rainfall event $(0.2 \mathrm{~mm})$ recorded that day (Fig. 2a) which would also yield an enriched $\delta^{18} \mathrm{O}$ signature. Larger rainfall events in our record (e.g. $8.4 \mathrm{~mm}$ on day 166), however, did not correspond to enriched $\delta^{18} \mathrm{O}$ runoff values. Furthermore, rainfall events should increase stream discharge, whereas we observed a decrease in stream discharge during this event.

\subsection{Mixing-model sensitivity analysis}

The sensitivity analysis revealed that for the entire dataset (May and July) the contribution from the surface snow reservoir to the total outflow varied from a mean maximum of $26 \%$ to a mean minimum of $0.9 \%$. Similarly, the delayedflow fraction varied from a mean maximum of $26 \%$ to a slightly higher mean minimum of $3.4 \%$. Not surprisingly, the glacial ice fraction exhibited the highest mean maximum and minimum values, varying from $97 \%$ to $49 \%$. Results of the sensitivity analysis are also displayed as the maximum and minimum flow contributions $\left(\mathrm{m}^{3} \mathrm{~s}^{-1}\right)$ from the surface snow, glacial ice and delayed-flow reservoirs from May (Fig. 6a) and July (Fig. 6b). In order to identify meaningful estimates, we constrained the sensitivity analysis so that no flow contribution was permitted to fluctuate below zero. When discharge was very low, we were not able to differentiate the flow contribution $\left(\mathrm{m}^{3} \mathrm{~s}^{-1}\right)$ from the different component reservoirs accurately (Fig. 6a). Additionally, though we were able to drive the snow contribution to zero, there was always a delayed-flow component that is diluted by an increasing ice component throughout the season. This analysis illustrates that we are currently able to determine the flow contribution from each of the defined water source reservoirs within an absolute maximum and minimum value. Further improvements to the flow estimates would benefit most from better characterization of the delayed-flow radon end-member.

\section{TRANSIT TIME ESTIMATES}

We observed detectable ${ }^{7}$ Be activity $\left(7.7 \mathrm{dpm} \mathrm{L}^{-1}\right)$ in the ${ }^{N}{ }^{\prime}$ supraglacial pond in May, which we use as an analogue for the potential ${ }^{7} \mathrm{Be}$ activity of surface snow in this study. This 

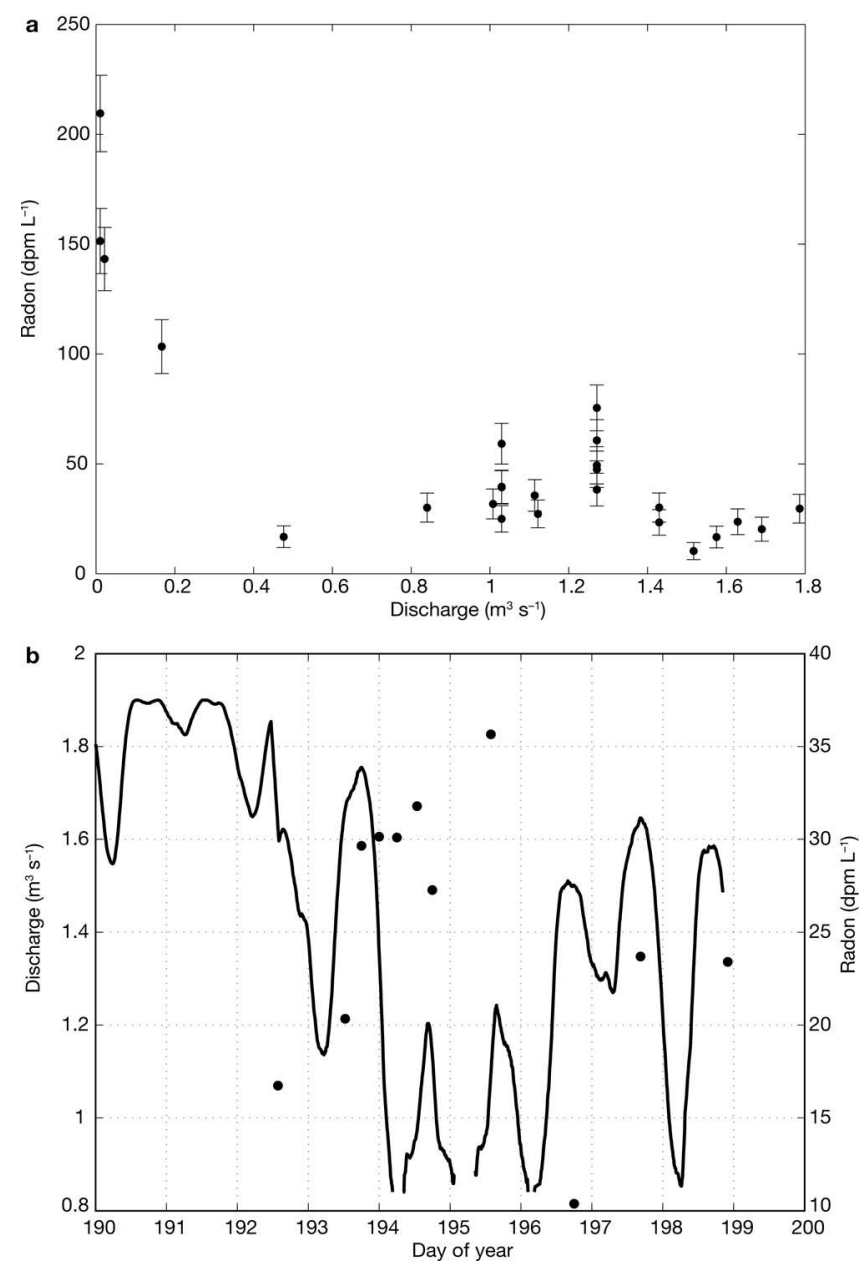

Fig. 5. (a) Radon activities ( \pm one standard error) in the ' $N$ ' glacier outflow stream plotted against daily average discharge, and (b) 3 hour average discharge and measured radon activities in the ' $N$ ' glacier outflow stream from 11 to 17 July. Discontinuous lines in the discharge record reflect gaps in the data. activity is within the range of previously reported ${ }^{7} \mathrm{Be}$ activities in fresh snow at Summit, Greenland (2.67$76.5 \mathrm{dpm} \mathrm{L}^{-1}$ ), but below the reported median $(15.3 \mathrm{dpm}$ $\mathrm{L}^{-1}$ ) (Dibb, 1990). The wide variability in reported freshsnow ${ }^{7} \mathrm{Be}$ activities likely reflects atmospheric inventory depletion and wet deposition-related dilution effects of precipitation-event frequency and duration (Nimz, 1998). For example, high ${ }^{7} \mathrm{Be}$ activities may result from a short snowfall event following a period of minimal precipitation. Conversely, lower snow activities may be explained by a relatively large snowfall event following a series of recent precipitation events. Our sample may have had lower ${ }^{7} \mathrm{Be}$ activity compared to the fresh snow collected at Summit because it represents a composite of fresh and older snow on the surface of ' $\mathrm{N}$ ' glacier. Comparatively, meltwater derived from recent glacial ice melt measured at the inland site in

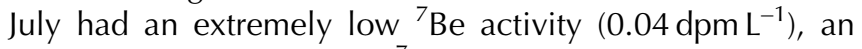
indication that its original ${ }^{7} \mathrm{Be}$ inventory had been lost via decay. Thus, ${ }^{7} \mathrm{Be}$ in outflow water can only be derived from a young supraglacial source that has originated at the surface $<1$ year before. On 21 May the ${ }^{7}$ Be activity of the ' $N$ ' glacier outflow stream was $1.05 \mathrm{dpm} \mathrm{L}^{-1}$, and on 11 July the ${ }^{7} \mathrm{Be}$

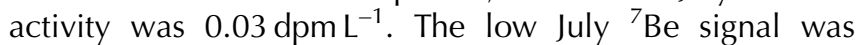
similar to the recent glacial ice-melt ${ }^{7} \mathrm{Be}$ signal, and most likely represented a switch in end-member contribution from snowmelt to ice melt. The May value, however, was consistent with a hydrological connection between surface melt and subsurface discharge at this point in the season. However, we cannot rule out the possibility that the May ${ }^{7}$ Be signal in the ${ }^{N}$ ' glacier outflow stream resulted from the release of supraglacial waters that had been stored at the bed for $<300$ days or in basal crevasses (Harper and others, 2010).

We used the fractions from the isotope-mixing model for the surface snow and glacial ice contributions on 21 May to solve for a transit time (Equation (7)). Since ${ }^{7} \mathrm{Be}$ is particlereactive (Hawley and others, 1986; Olsen and others, 1986)
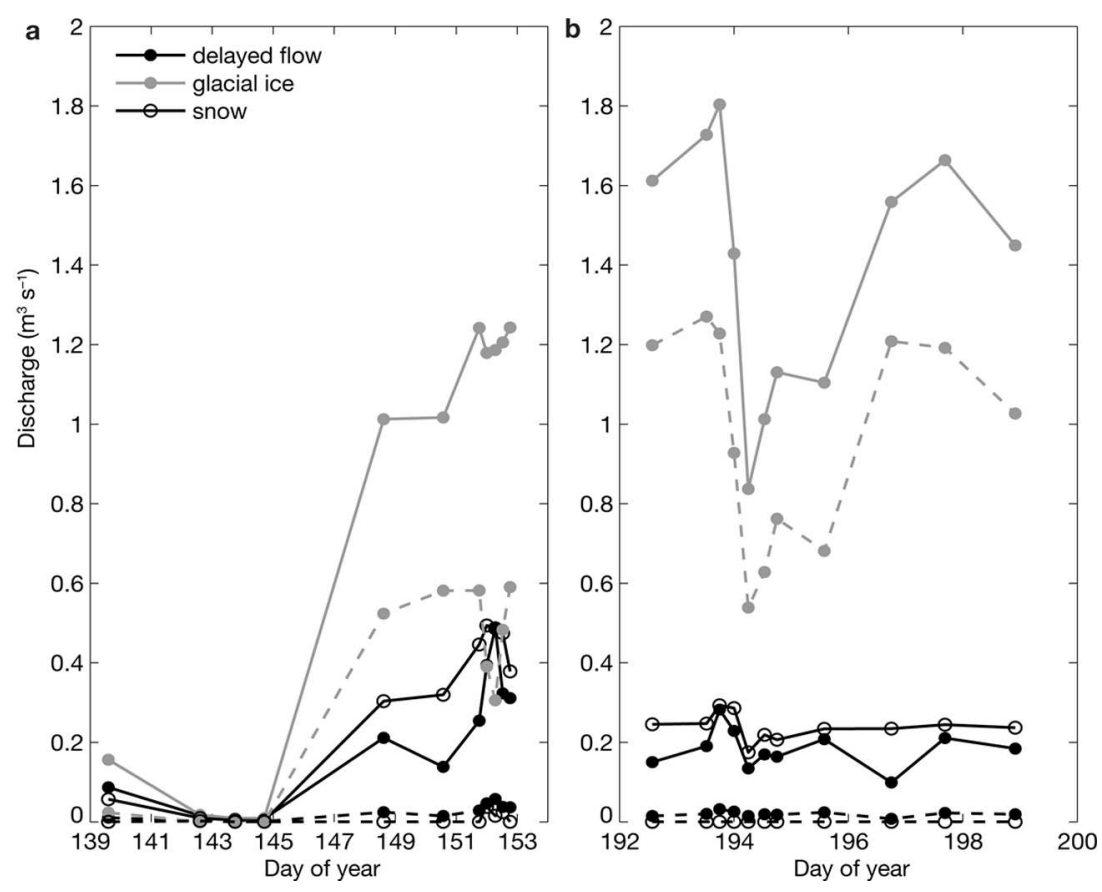

Fig. 6. Sensitivity analysis illustrating maximum (solid lines) and minimum (dashed lines) flow contributions from the surface snow, glacial ice and delayed-flow water sources from (a) 18 May to 1 June and (b) 11 to 17 July. 
and thus could have adsorbed to solids during travel through the subglacial environment, we also included a correction that describes scavenging of ${ }^{7} \mathrm{Be}$ onto particles in the subglacial environment (Equation (6)). Given these assumptions, we estimated that supraglacial waters took $\sim 7.5$ days to travel from the surface to the glacier mouth. For comparison, distributed drainage-system transit times (estimated using velocities from dye-tracing experiments in Nienow and others, 1998) at Haut Glacier d'Arolla, Switzerland, which has a similar catchment size to ' $\mathrm{N}$ ' glacier, range from $\sim 6$ to $<1$ day(s) for a $5 \mathrm{~km}$ flow path. However, we should note that our calculated time estimate depends on the accuracy of our assumed partition coefficient, $K_{\mathrm{d}}$, and the surface ${ }^{7}$ Be activity. Nonetheless, ${ }^{7}$ Be may hold promise as a tracer for snowmelt in early-season distributed drainage systems with similar or longer transit times.

\section{SYNTHESIS}

Results from our multi-component isotope-mixing model provide broad separation of water reservoir contributions, thus providing a potential new direction in the application of chemical mixing models to study glacier hydrology. Based on the results from this study, we furthermore suggest that these methods could be successfully scaled up to investigate the subglacial hydrology of the much larger outlet glaciers that drain the bulk of the GrIS. Some practical and technological challenges remain to be solved in regularly sampling discharge and radon at large land-terminating glaciers (e.g. in flood plains, large channels or braided river environments) and in large marine-terminating glaciers (tidewater environments). This effort would also require comprehensive sampling of the glacial ice end-member water isotope values across each of these larger catchments.

Focusing our study on a small land-terminating glacier on the southwestern margin of the GrIS, we show that there is a relatively constant and chemically enriched delayed (basal) flow component present throughout the melt season. These delayed-flow waters comprise a greater fraction of the total discharge in May compared to July, and are diluted first by snowmelt and then by increasing amounts of rapidly flowing ice melt as the season progresses. In alpine glaciers, chemically enriched delayed-flow waters (e.g. snowmelt, basal melt, groundwater) are characteristic of distributed drainage systems, which transmit meltwater slowly through the glacier via a hydraulically inefficient network. As the snowline retreats and surface meltwater input to the bed increases, the subglacial drainage system structure evolves to a channelized drainage system, which can more efficiently export the surface glacial ice melt. Though such seasonal subglacial drainage evolution is well documented in alpine systems (Hubbard and Nienow, 1997; Nienow and others, 1998; Cuffey and Paterson, 2010), its existence under land-terminating sectors of the GrIS has only recently been hypothesized (Shepherd and others, 2009; Bartholomew and others, 2010) and has not been directly observed. The findings from this study offer a hydrochemical line of evidence for this hypothesis, albeit at a comparatively much smaller outlet glacier, and bolster the need to incorporate these dynamically significant subglacial processes into GrlS modeling efforts.

From a biogeochemical perspective, knowledge of the seasonal controls on end-member water-source contributors to bulk discharge provides greater understanding of the potential for high temporal variability of carbon, nutrient and metal export from subglacial environments to downstream marine ecosystems. Previous studies have suggested that water draining a distributed drainage system contains much greater concentrations of these biogeochemically important species, compared to the waters draining a channelized system (Tranter and others, 2005). Thus, total annual flux calculations of carbon, nutrient and metal export require knowledge of the base flow $\left(\mathrm{m}^{3} \mathrm{a}^{-1}\right)$ exiting a glacier. Our isotope-mixing model shows promise at being able to provide reasonable quantitative estimates of snow, ice and delayed-flow components comprising bulk meltwater discharge from a land-terminating GrlS glacier. These flow estimates can be used as a first-order approximation of base flow emanating from similar catchments around the GrIS throughout the year.

\section{ACKNOWLEDGEMENTS}

This research was supported by the WHOI Clark Arctic Research Initiative (E.B.K., S.B.D., M.A.C.), the WHOI Ocean Ventures Fund (M.P.B.), the US National Science Foundation ARC-05200077 (S.B.D.), NASA (S.B.D.), the Natural Sciences and Engineering Research Council of Canada (M.P.B.) and the WHOI Climate Change Institute (M.P.B.). We acknowledge I. Joughin for kindly providing InSAR velocity data. We are very grateful to $M$. Behn and D. Glover for assistance with data analysis, to M. Sharp and K. Longnecker for comments and advice that improved the manuscript, and to B. Gready, M. Behn, I. Joughin, M. Evans, A. Criscitello and R. Harris for assistance in the field.

\section{REFERENCES}

Andrews, J.E., C. Hartin and K.O. Buesseler. 2008. ${ }^{7}$ Be analyses in seawater by low background gamma-spectroscopy. J. Radioanal. Nucl. Chem., 277(1), 253-259.

Bartholomew, I., P. Nienow, D. Mair, A. Hubbard, M.A. King and A. Sole. 2010. Seasonal evolution of subglacial drainage and acceleration in a Greenland outlet glacier. Nature Geosci., 3(6), 408-411.

Benn, D.I. and D.J.A. Evans. 1998. Glaciers and glaciation. London, Arnold.

Bhatia, M.P., S.B. Das, K. Longnecker, M.A. Charette and E.B. Kujawinski. 2010. Molecular characterization of dissolved organic matter associated with the Greenland ice sheet. Geochim. Cosmochim. Acta, 74(13), 3768-3784.

Box, J.E. and K. Ski. 2007. Remote sounding of Greenland supraglacial melt lakes: implications for subglacial hydraulics. J. Glaciol., 53(181), 257-265.

Box, J.E. and 8 others. 2006. Greenland ice sheet surface mass balance variability (1988-2004) from calibrated Polar MM5 output. J. Climate, 19(12), 2783-2800.

Broecker, W.S. and T.H. Peng. 1982. Tracers in the sea. New York, Eldigio Press.

Brown, G.H. 2002. Glacier meltwater hydrochemistry. Appl. Geochem., 17(7), 855-883.

Brown, G.H., M.J. Sharp, M. Tranter, A.M. Gurnell and P.W. Nienow. 1994. Impact of post-mixing chemical reactions on the major ion chemistry of bulk meltwaters draining the Haut Glacier d'Arolla, Valais, Switzerland. Hydrol. Process., 8(5), 465-480.

Burnett, W.C. and H. Dulaiova. 2003. Estimating the dynamics of groundwater input into the coastal zone via continuous radon222 measurements. J. Environ. Radioactiv., 69(1-2), 21-35. 
Cable, J.E., W.C. Burnett, J.P. Chanton and G.L. Weatherly. 1996. Estimating groundwater discharge into the northeastern Gulf of Mexico using radon-222. Earth Planet. Sci. Lett., 144(3-4), 591-604.

Charette, M.A., W.S. Moore and W.C. Burnett. 2008. Uraniumand thorium-series nuclides as tracers of submarine groundwater discharge. In Krishnaswami, S. and J. Kirk Cochran, eds. $U$-Th series nuclides in aquatic systems. Amsterdam, Elsevier, 155-191. (Radioactivity in the Environment 13.)

Clark, I.D. and P. Fritz. 1997. Environmental isotopes in hydrogeology. Boca Raton, FL, CRC Lewis.

Collins, D.N. 1979. Quantitative determination of the subglacial hydrology of two Alpine glaciers. J. Glaciol., 23(89), 347-362.

Cooper, L.W. 1998. Isotopic fractionation in snow cover. In Kendall, C. and J.J. McDonnell, eds. Isotope tracers in catchment hydrology. New York, Elsevier, 119-136.

Corbett, D.R., W.C. Burnett, P.H. Cable and S.B. Clark. 1997. Radon tracing of groundwater input into Par Pond, Savannah River Site. J. Hydrol., 203(1-4), 209-227.

Craig, H. 1961. Isotopic variations in meteoric waters. Science, 133(3465), 1702-1703.

Cuffey, K.M. and W.S.B. Paterson. 2010. The physics of glaciers. Fourth edition. Oxford, Butterworth-Heinemann.

Dansgaard, W., S.J. Johnsen, H.B. Clausen and N. Gundestrup. 1973. Stable isotope glaciology. Medd. Grønl., 197(2), 1-53.

Das, S.B. and 6 others. 2008. Fracture propagation to the base of the Greenland Ice Sheet during supraglacial lake drainage. Science, 320(5877), 778-781.

Dibb, J.E. 1990. Beryllium-7 and lead-210 in the atmosphere and surface snow over the Greenland ice sheet in the summer of 1989. J. Geophys. Res., 95(D13), 22,407-22,415.

Dingman, S.L. 2002. Physical hydrology. Second edition. Long Grove, IL, Waveland Press.

Dulaiova, H., R. Peterson, W.C. Burnett and D. Lane-Smith. 2005. A multi-detector continuous monitor for assessment of ${ }^{222} \mathrm{Rn}$ in the coastal ocean. J. Radioanal. Nucl. Chem., 263(2), 361-363.

Dulaiova, H., M.E. Gonneea, P.B. Henderson and M.A. Charette. 2008. Geochemical and physical sources of radon variation in a subterranean estuary - implications for groundwater radon activities in submarine groundwater discharge studies. Mar. Chem., 110(1-2), 120-127.

Gurnell, A.M. and C.R. Fenn. 1984. Flow separation, sediment source areas and suspended sediment transport in a pro-glacial stream. Catena, Suppl. 5, 109-119.

Harper, J.T., J.H. Bradford, N.F. Humphrey and T.W. Meierbachtol. 2010. Vertical extension of the subglacial drainage system into basal crevasses. Nature, 467(7315), 579-582.

Hawley, N., J.A. Robbins and B.J. Eadie. 1986. The partitioning of ${ }^{7}$ beryllium in fresh water. Geochim. Cosmochim. Acta, 50(6), 1127-1131.

Hood, E. and D. Scott. 2008. Riverine organic matter and nutrients in southeast Alaska affected by glacial coverage. Nature Geosci., 1(9), 583-587.

Hood, E. and 6 others. 2009. Glaciers as a source of ancient and labile organic matter to the marine environment. Nature, 462(7276), 1044-1047.

Hubbard, B. and P. Nienow. 1997. Alpine subglacial hydrology. Quat. Sci. Rev., 16(9), 939-955.

Joughin, I., S.B. Das, M.A. King, B.E. Smith, I.M. Howat and T. Moon. 2008. Seasonal speedup along the western flank of the Greenland Ice Sheet. Science, 320(5877), 781-783.

Jouzel, J. and 12 others. 1997. Validity of the temperature reconstruction from water isotopes in ice cores. J. Geophys. Res., 102(C12), 26,471-26,487.

Kies, A., O. Hengesch, Z. Tosheva, J. Jania and A. Nawrot. 2010. Natural radioactive isotopes in glacier studies. In Barnet, I. and P. Pacherová, eds. Proceedings of the 10th International Workshop on the Geological Aspects of Radon Risk Mapping, 22-25 September 2010, Prague, Czech Republic. Prague, Czech Geological Survey, 162-172.
Kraemer, T.F. and D.P. Genereux. 1998. Applications of uraniumand thorium-series radionuclides in catchment hydrology studies. In Kendall, C. and J.J. McDonnell, eds. Isotope tracers in catchment hydrology. New York, Elsevier, 679-722.

Krawczynski, M.J., M.D. Behn, S.B. Das and I. Joughin. 2009. Constraints on the lake volume required for hydro-fracture through ice sheets. Geophys. Res. Lett., 36(10), L10501. (10.1029/2008GL036765.)

McMillan, M., P. Nienow, A. Shepherd, T. Benham and A. Sole. 2007. Seasonal evolution of supra-glacial lakes on the Greenland Ice Sheet. Earth Planet. Sci. Lett., 262(3-4), 484-492.

Mernild, S.H., G.E. Liston, C.A. Hiemstra, K. Steffen, E. Hanna and J.H. Christensen. 2009. Greenland ice sheet surface massbalance modelling and freshwater flux for 2007, and in a 19952007 perspective. Hydrol. Process., 23(17), 2470-2484.

Mitchell, A., G.H. Brown and R. Fuge. 2001. Minor and trace element export from glacierized Alpine headwater catchment (Haut Glacier d'Arolla, Switzerland). Hydrol. Process., 15(18), 3499-3524.

Nienow, P., M. Sharp and I. Willis. 1998. Seasonal changes in the morphology of the subglacial drainage system, Haut Glacier d'Arolla, Switzerland. Earth Surf. Process. Landf., 23(9), 825-843.

Nimz, G.J. 1998. Lithogenic and cosmogenic tracers in catchment hydrology. In Kendall, C. and J.J. McDonnell, eds. Isotope tracers in catchment hydrology. New York, Elsevier, 247-289.

Olsen, C.R., I.L. Larsen, P.D. Lowry, N.H. Cutshall and M.M. Nichols. 1986. Geochemistry and deposition of ${ }^{7} \mathrm{Be}$ in river-estuarine and coastal waters. J. Geophys. Res., 91(C1), 896-908.

Paterson, W.S.B. 1994. The physics of glaciers. Third edition. Oxford, etc., Elsevier.

Raiswell, R. and 6 others. 2006. Contributions from glacially derived sediment to the global iron (oxyhydr)oxide cycle: implications for iron delivery to the oceans. Geochim. Cosmochim. Acta, 70(11), 2765-2780.

Reeh, N. and H.H. Thomsen. 1993. Using stable isotopes as natural tracers to delineate hydrological drainage basins on the Greenland ice-sheet margin. Chemical Geol., 109(1-4), 281-291.

Richards, K.S. and 9 others. 1996. An integrated approach to modelling hydrology and water quality in glacierized catchments. Hydrol. Process., 10(4), 479-508.

Richter-Menge, J., ed. 2009. The Arctic. Bull. Am. Meteorol. Soc., 90, Special issue, S1-S196.

Ricker, W.E. 1973. Linear regressions in fishery research. J. Fish. Res. Board Can., 30(3), 409-434.

Schmidt, A., M. Schlueter, M. Melles and M. Schubert. 2008. Continuous and discrete on-site detection of radon-222 in ground- and surface waters by means of an extraction module. Appl. Radiat. Isotop., 66(12), 1939-1944.

Sharp, M., G.H. Brown, M. Tranter, I.C. Willis and B. Hubbard. 1995. Comments on the use of chemically based mixing models in glacier hydrology. J. Glaciol., 41(138), 241-246.

Sharp, M., J. Parkes, B. Cragg, I.J. Fairchild, H. Lamb and M. Tranter. 1999. Widespread bacterial populations at glacier beds and their relationship to rock weathering and carbon cycling. Geology, 27(2), 107-110.

Shepherd, A., A. Hubbard, P. Nienow, M. McMillan and I. Joughin. 2009. Greenland ice sheet motion coupled with daily melting in late summer. Geophys. Res. Lett., 36(1), L01501. (10.1029/ 2008GL035758.)

Skidmore, M.L., J.M. Foght and M.J. Sharp. 2000. Microbial life beneath a High Arctic glacier. Appl. Environ. Microbiol., 66(8), $3214-3220$.

Sokal, R.R. and F.J. Rohlf. 1995. Biometry: the principles and practice of statistics in biological research. Third edition. New York, W.H. Freeman.

Solomon, S. and 7 others, eds. 2007. Climate change 2007: the physical science basis. Contribution of Working Group I to the 
Fourth Assessment Report of the Intergovernmental Panel on Climate Change. Cambridge, etc., Cambridge University Press.

Taylor, S., X. Feng, J.W. Kirchner, R. Osterhuber, B. Klaue and C.C. Renshaw. 2001. Isotopic evolution of a seasonal snowpack and its melt. Water Resour. Res., 37(3), 759-769.

Theakstone, W.H. 2003. Oxygen isotopes in glacier-river water, Austre Okstindbreen, Okstindan, Norway. J. Glaciol., 49(165), 282-298.

Tranter, M. and R. Raiswell. 1991. The composition of the englacial and subglacial component in bulk meltwaters draining the Gornergletscher, Switzerland. J. Glaciol., 37(125), 59-66.

Tranter, M. and 9 others. 1997. Variability in the chemical composition of in situ subglacial meltwaters. Hydrol. Process., 11(1), 59-78.
Tranter, M., M.J. Sharp, H.R. Lamb, G.H. Brown, B.P. Hubbard and I.C. Willis. 2002. Geochemical weathering at the bed of Haut Glacier d'Arolla, Switzerland - a new model. Hydrol. Process., 16(5), 959-993.

Tranter, M., M. Skidmore and J. Wadham. 2005. Hydrological controls on microbial communities in subglacial environments. Hydrol. Process., 19(4), 995-998.

Tsai, V.C. and J.R. Rice. 2010. A model for turbulent hydraulic fracture and application to crack propagation at glacier beds. J. Geophys. Res., 115(F3), F03007. (10.1029/2009JF001474.)

Wadham, J.L., M. Tranter, S. Tulaczyk and M. Sharp. 2008. Subglacial methanogenesis: a potential climatic amplifier? Global Biogeochem. Cycles, 22(2), GB2021. (10.1029/ 2007GB002951.)

MS received 30 November 2010 and accepted in revised form 23 July 2011 